\title{
Algoritma Genetika untuk Pemecahan Masalah Rute Kendaraan dengan Ukuran dan Campuran Armada, Trip Majemuk, Pengiriman Terbagi, Produk Majemuk dan Kendaraan dengan Kompartemen Majemuk
}

\author{
Suprayogi ${ }^{*}$, Daniel Bunga Paillin ${ }^{2}$
}

\begin{abstract}
This paper discusses a variant of the basic vehicle routing problem (VRP) by including the following characteristics: fleet size and mix, multiple trips, split delivery, multiple products, and multiple compartments. One of real cases of this problem is related to determining tanker's routes in delivering fuel products from a supply port to a number of destination ports. Each tanker has several compartments where each compartment is dedicated to a certain fuel product. In this paper, a solution approach based on genetic algorithm (GA) is proposed and tested using nine hypothetical instances. Experiment results show that the proposed GA gives consistent results measured by coefficient variations.
\end{abstract}

Keywords: Vehicle routing problem, fleet size and mix, multiple trips, split delivery, multiple compartments, genetic algorithm.

\section{Pendahuluan}

Makalah ini membahas salah satu varian dari masalah rute kendaraan (MRK) dengan karakteristik-karakteristik berikut: ukuran dan campuran armada (fleet size and mix), trip majemuk (multiple trips), pengiriman terbagi (split delivery), produk majemuk (multiple products), dan kompartemen majemuk (multiple compartments). Salah satu masalah nyata adalah terkait dengan penentuan rute tanker untuk pengiriman produk-produk bahan bakar minyak (BBM) dari sebuah pelabuhan pasokan (depot) ke sejumlah pelabuhan tujuan. Pengiriman produk-produk BBM mengunakan tanker-tanker yang berpangkalan di depot. Terdapat satu himpunan jenis tanker dengan tiap jenis memiliki biaya tetap, biaya variabel, kecepatan, dan kapasitas tiap kompartemen yang tertentu.

MRK dasar, seperti diperkenalkan oleh Dantzig dan Ramser [1], mengasumsikan bahwa kendaraan-kendaraan hanya memiliki satu jenis saja dengan karakteristik yang homogen. Dalam konteks armada kendaraan campuran, terdapat satu himpunan jenis kendaraan dengan tiap jenis kendaraan diasumsikan tak terbatas. Tiap jenis kendaraan memiliki karakteristik-karakteristik tertentu seperti kapasitas, kecepatan, biaya tetap dan biaya variabel.

\footnotetext{
${ }^{1}$ Fakultas Teknologi Industri, Institut Teknologi Bandung, Jl. Ganesha 10, Bandung 40132, Indonesia. Email: yogi@mail.ti.itb.ac.id.

${ }^{2}$ Fakultas Teknik, Program Studi Teknik Industri, Universitas Pattimura, Jl. Ir. M. Putuhena, Kampus Poka, Ambon, 97233 Indonesia. Email: dani_ti_fatek@yahoo.co.id

* Penulis korespondensi
}

Dalam literatur, varian MRK ini disebut dengan MRK dengan campuran armada (VRP with fleet mix) seperti pada Wassan and Osman [2] dan Lee et al. [3] atau MRK dengan ukuran dan campuran armada (VRP with fleet size and mix) seperti yang terdapat pada Gheysens et al. [4].

MRK dasar memiliki asumsi bahwa tiap kendaraan hanya melayani satu rute sepanjang horison perencanaan. Dalam situasi praktis, adakalanya tiap kendaraan diijinkan untuk melayani satu atau lebih rute sepanjang horison perencanaan tidak dilanggar. Varian MRK ini disebut dengan MRK dengan trip majemuk. Dalam literatur, MRK dengan trip majemuk dikenal juga dengan istilah MRK dengan pengunaan kendaraan majemuk (VRP with multiple use of vehicles). Dalam konteks trip majemuk, terdapat dua istilah yang umum digunakan seperti didefinisikan oleh Brandão and Mercer [5], yaitu rute (trip) dan tur. Suatu rute (trip) merupakan suatu urut-urutan kunjungan kendaraan yang berawal dan berakhir di depot. Suatu tur merupakan kumpulan satu atau lebih rute atau trip yang dilayani oleh satu kendaraan yang sama. Beberapa penelitian dalam MRK dengan trip majemuk antara lain adalah Taillard et al. [6], Brandão and Mercer [5], Brandão and Mercer [7], Zhao et al. [8], Petch and Salhi [9], dan Salhi and Petch [10].

Dalam MRK dasar, tiap pelanggan tepat dikunjungi satu kali sepanjang horizon perencanaan. Hal ini terjadi karena kuantitas pengiriman untuk tiap pelanggan diasumsikan lebih kecil atau sama dengan kapasitas kendaraan. Dalam kondisi terdapat kuantitas permintaan pengiriman dari pelanggan yang melebihi kapasitas kendaraan, maka pelanggan 
tersebut dikunjungi lebih dari satu kali, baik oleh kendaraan yang sama maupun berbeda. Dalam konteks ini, varian MRK yang dibahas adalah MRK dengan pengiriman terbagi (split delivery). Beberapa penelitian yang terkait dengan MRK dengan pengiriman terbagi antara lain adalah Dror et al. [11], Archetti et al. [12], Boudia et al. [13], TavakkoliMoghaddam et al. [14], Derigs et al. [15], dan Wilck IV and Cavalier [16].

MRK dasar mengasumsikan bahwa masalah hanya terkait dengan produk tunggal dengan kendaraan hanya memiliki satu kompartemen. MRK yang dibahas dalam makalah ini mencakup produk majemuk dan kendaraan memiliki beberapa kompartemen dengan tiap kompartemen diperuntukkan bagi produk tertentu. Varian MRK ini telah dibahas oleh Christofides et al. [17]. Penelitian lainnya, antara lain, adalah Chajakis and Guignard [18], Avella et al. [19], El Fallahi et al. [20], Derigs et al. [21], dan Reed et al. [22].

Suprayogi dan Komara [23] telah membahas MRK dengan karakteristik trip majemuk, pengiriman terbagi, produk majemuk, dan kendaraan dengan kompartemen majemuk. Metode heuristik konstruksi yang didasarkan atas penyisipan sekuensial (sequential insertion) diusulkan sebagai metode pemecahan. Suprayogi et al. [24] mengembangkan metode heuristik perbaikan berupa metode pencarian lokal (local search) untuk memecahkan MRK yang dibahas oleh Suprayogi dan Komara [23]. Suprayogi dan Arvianto [25] menambahkan karakteristik jendela waktu majemuk (multiple time windows) pada MRK yang dibahas oleh Suprayogi dan Komara [23] dan Suprayogi et al. [24]. Metode pencarian lokal dikembangkan sebagai metode pemecahan. Arvianto et al. [26] memasukkan aspek ukuran dan campuran armada pada Suprayogi dan Arvianto [25] dan mengunakan metode pencarian lokal untuk memecahkannya.

Makalah ini membahas MRK dengan karakteristik trip majemuk, pengiriman terbagi, produk majemuk, dan kendaraan dengan kompartemen majemuk. Paillin dan Wattimena [27] menerapkan algoritma penyisipan sekuensial untuk kasus pendistribusian BBM di kawasan timur Indonesia. Kontribusi dari makalah ini terletak pada pengembangan metode algoritma genetika (AG) atau genetic algorithm (GA). Metode AG merupakan salah satu metode metaheuristik yang mengambil analogi dari konsep evolusi yang mengeksplorasi ruang solusi secara probabilistik. AG banyak digunakan untuk memecahkan masalah-masalah optimisasi kombinatorial, termasuk MRK.

\section{Metode Penelitian}

\section{Definisi Masalah}

Definisi MRK yang dibahas dalam makalah ini adalah sebagai berikut. Terdapat satu himpunan titik lokasi yang terdiri dari sebuah depot dan sejumlah pelanggan. Jarak antara titik lokasi adalah diketahui dan diasumsikan simetris. Dalam horison perencanaan, tiap pelanggan memiliki kuantitas permintaan pengiriman untuk beberapa jenis produk dengan kuantitas yang diketahui. Pemuatan produk-produk dilakukan di depot dan pembongkaran produk-produk dilakukan di pelanggan. Pengiriman produk-produk dapat dilakukan dengan beberapa jenis kendaraan yang diasumsikan berpangkalan di depot. Tiap jenis kendaraan memiliki beberapa kompartemen dengan tiap kompartemen diperuntukkan bagi tiap produk. Tiap jenis kendaraan memiliki komponen biaya yang terdiri dari biaya tetap dan biaya variabel per satuan waktu. Tiap jenis kendaraan juga memiliki kecepatan yang tertentu dengan asumsi bahwa kecepatan adalah tetap. Panjang horizon perencanaan adalah diketahui. MRK terkait dengan penentuan jenis kendaraan yang dipilih dan tur untuk tiap kendaraan sepanjang horison perencanaan yang meminimumkan total biaya yang memenuhi pembataspembatas sebagai berikut: (1) tiap tur dapat terdiri dari satu atau lebih rute (rute majemuk) dengan tiap rute berawal dan berakhir di depot, (2) kapasitas tiap kompartemen untuk setiap rute kendaraan tidak dilanggar, (3) tiap pelanggan dapat dikunjungi lebih dari satu kali, baik oleh kendaraan yang sama maupun berbeda (pengiriman terbagi), (4) seluruh pelanggan harus dilayani, dan (5) total waktu penyelesaian untuk tiap kendaraan tidak melebihi panjang horizon perencanaan.

Ilustrasi dari MRK yang dibahas dan solusinya ditunjukkan pada Gambar 1. Dalam ilustrasi, terdapat satu depot (disimbolkan dengan angka 0 ) dan sembilan pelanggan (disimbolkan dengan angka 1 sampai dengan 9). Tiap pelanggan memiliki permintaan untuk tiga jenis produk yang disimbolkan dengan $\mathrm{P}_{1}, \mathrm{P}_{2}$, dan $\mathrm{P}_{3}$. Solusi pada Gambar 1 memiliki tiga tur. Tur pertama dilayani oleh kendaraan jenis I yang terdiri atas dua rute (trip), yaitu: 0-7-6-0 dan 0-8-9-0. Kendaraan jenis I ini melayani trip majemuk. Tur kedua dilayani oleh kendaraan jenis II yang terdiri atas satu rute, (trip) yaitu: 0-1-23-0. Sedangkan tur ketiga dilayani oleh kendaraan jenis III yang tediri atas satu rute (trip), yaitu: 0-5-46-0. Di sini, kuantitas permintaan permintaan pada pelanggan 6 adalah terbagi, yang dilayani oleh kendaraan-kendaraan jenis I dan III. 


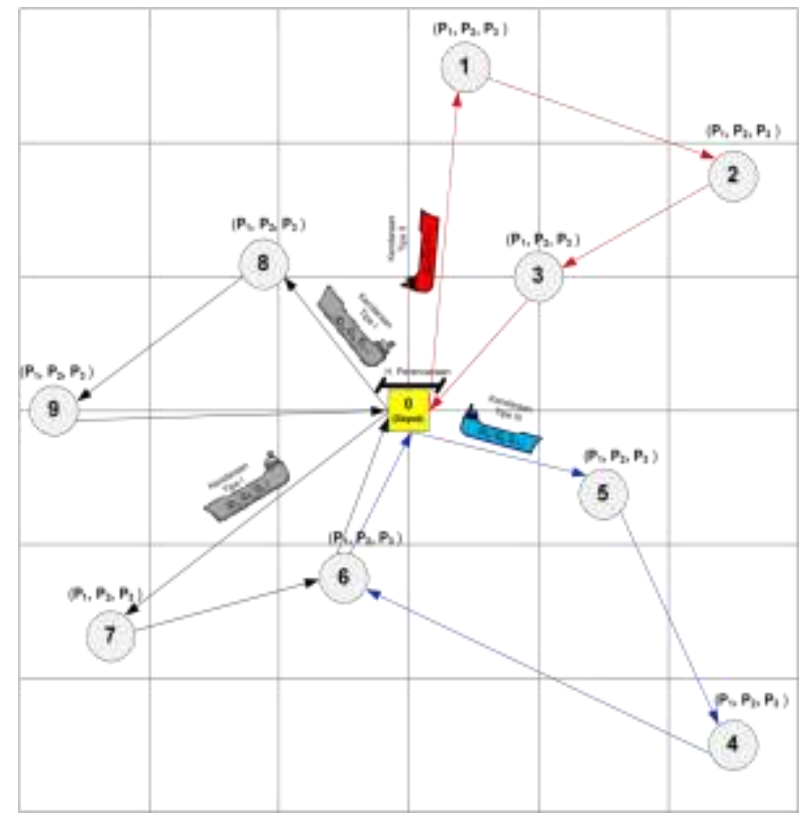

Gambar 1. Ilustrasi MRK dan solusinya

\section{Algoritma Genetika}

\section{Kerangka Umum}

Prosedur dari teknik AG yang diusulkan diperlihatkan pada Gambar 2. Untuk pembentukan populasi baru, terdapat empat operator yang digunakan, yaitu elistisme, migrasi, mutasi, dan crossover yang diterapkan secara paralel. Pemilihan induk untuk mutasi dan crossover dilakukan dengan metode roulette wheel.

Prosedur AG memerlukan parameter-parameter, yaitu: (1) ukuran populasi (jumlah kromosom atau individu dalam populasi), (2) proporsi-proporsi kromosom yang dibentuk dengan operator-operator elitisme, migrasi, mutasi, dan crossover, dan (3) jumlah generasi maksimum sebagai kriteria henti.

\section{Representasi Kromosom}

Kromosom direpresentasikan sebagai urutan bilangan bulat. Misal MRK terdiri atas satu depot dan $n$ pelanggan. Di sini, depot disimbolkan dengan angka 0 dan pelanggan-pelanggan dinotasikan dengan angka-angka 1 hingga $n$. Satu rute ditandai dengan urutan bilangan sejumlah tertentu yang diawali dan diakhiri dengan angka 0 . Karena terdapat karakteristik pengiriman terbagi, angka yang sama (mencerminkan pelanggan) dapat muncul lebih dari satu kali. Berikut adalah contoh representasi dari kromosom yang terdiri dari dua tur kendaraan dengan dua rute

$0-5-3-7-0-3-8-0$

$0-6-8-1-4-0-2-9-0$

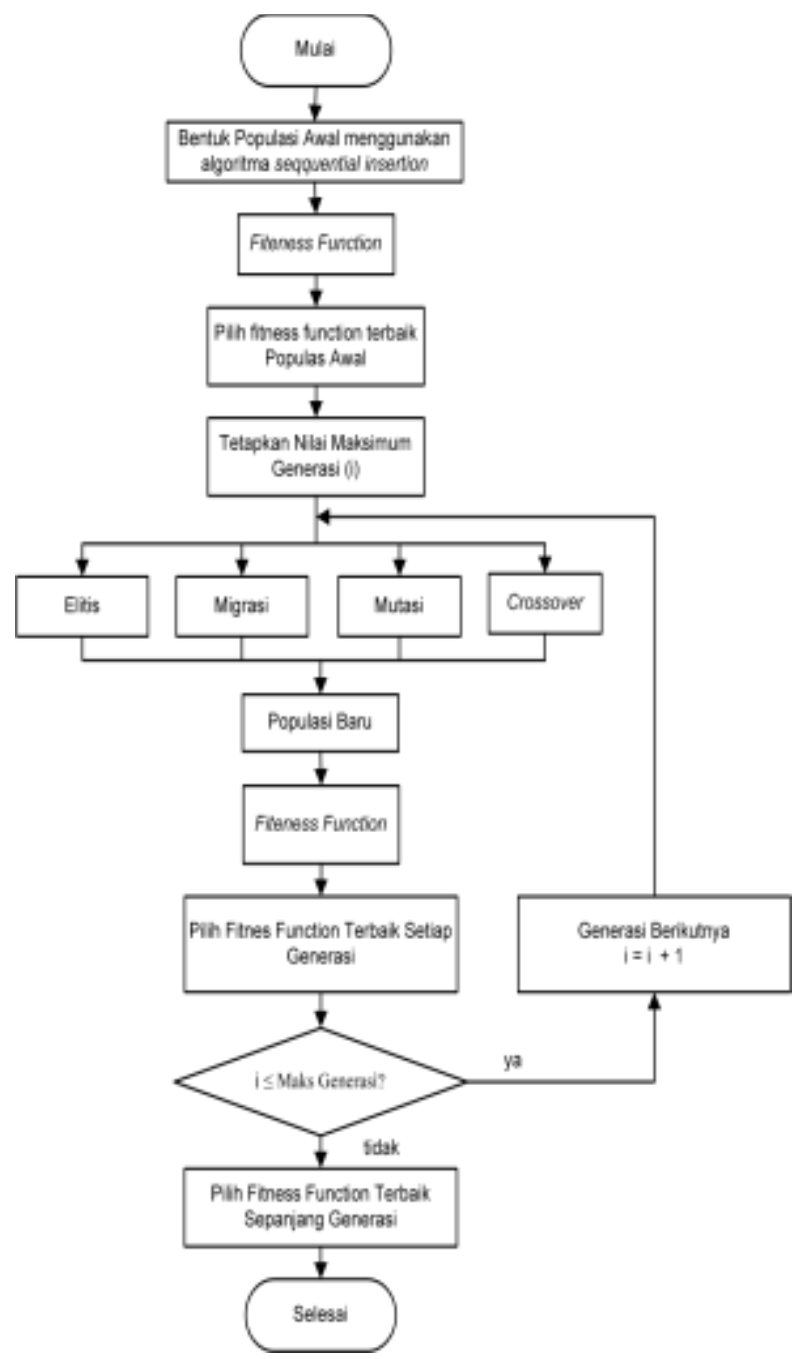

Gambar 2. Diagram alir prosedur AG

\section{Pembentukan Populasi Awal}

Tiap kromosom dalam populasi awal dibangkitkan dengan algoritma penyisipan sekuensial yang diambil dari Paillin dan Wattimena [27] yang pada awalnya diadaptasi dari Suprayogi dan Komara [23] dan Suprayogi et al. [24]. Diagram alir pembentukan suatu kromosom dalam populasi awal ditunjukkan pada Gambar 3.

\section{Fungsi Fitness}

Untuk tiap kromosom, AG menggunakan fungsi fitness yang meminimumkan total biaya yang merupakan penjumlahan dari biaya-biaya tetap dan variabel untuk masing-masing kendaraan yang terpilih.

\section{Operator-operator Reproduksi}

Elitisme. Operator reproduksi berfungsi untuk mengambil kromosom-kromosom terbaik dari populasi saat ini dan memasukkannya ke populasi berikutnya. Jumlah kromosom yang diambil ditentukan oleh proporsi tertentu. 


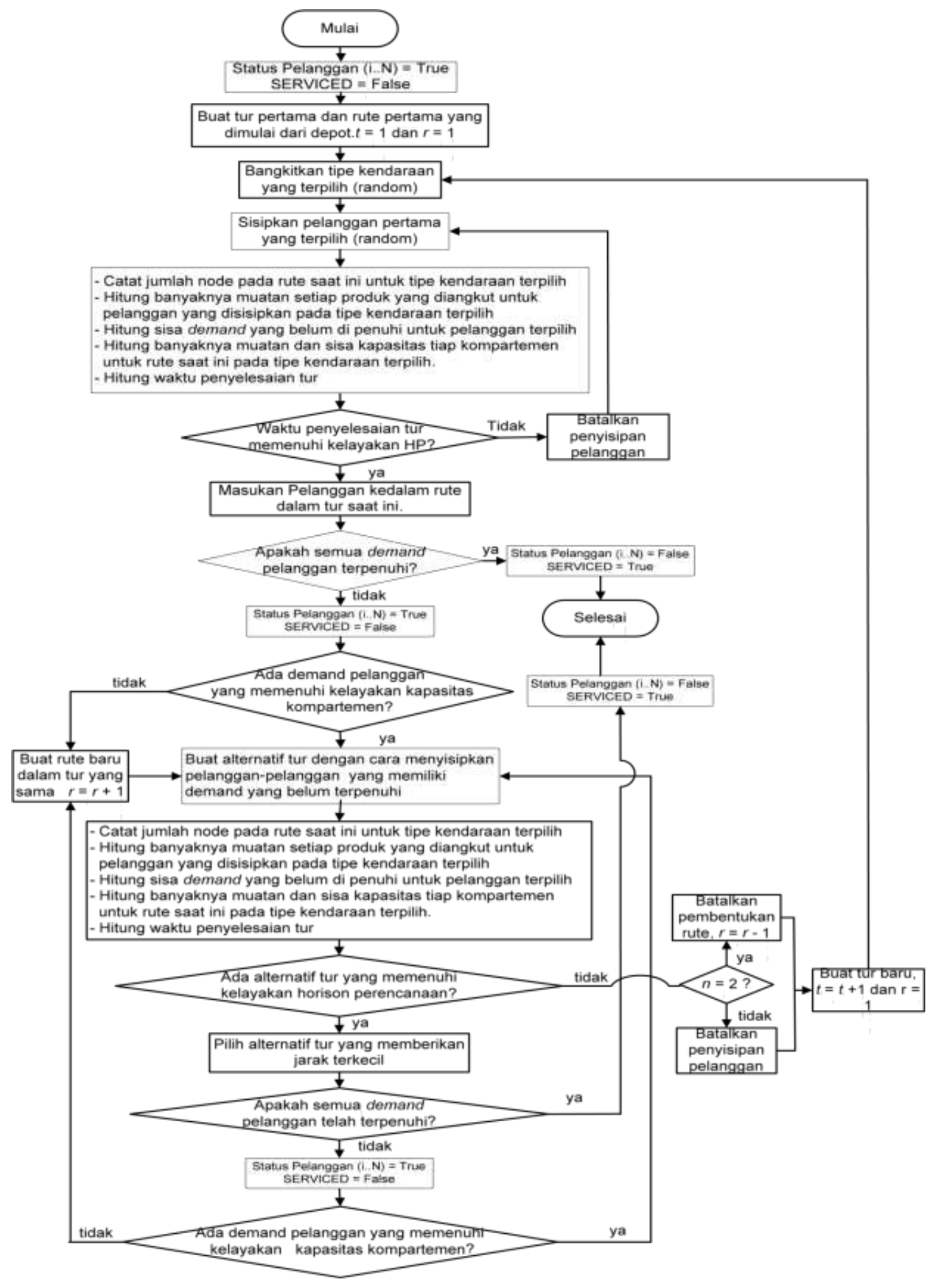

Gambar 3. Diagram alir pembentukan kromosom dalam populasi awal 


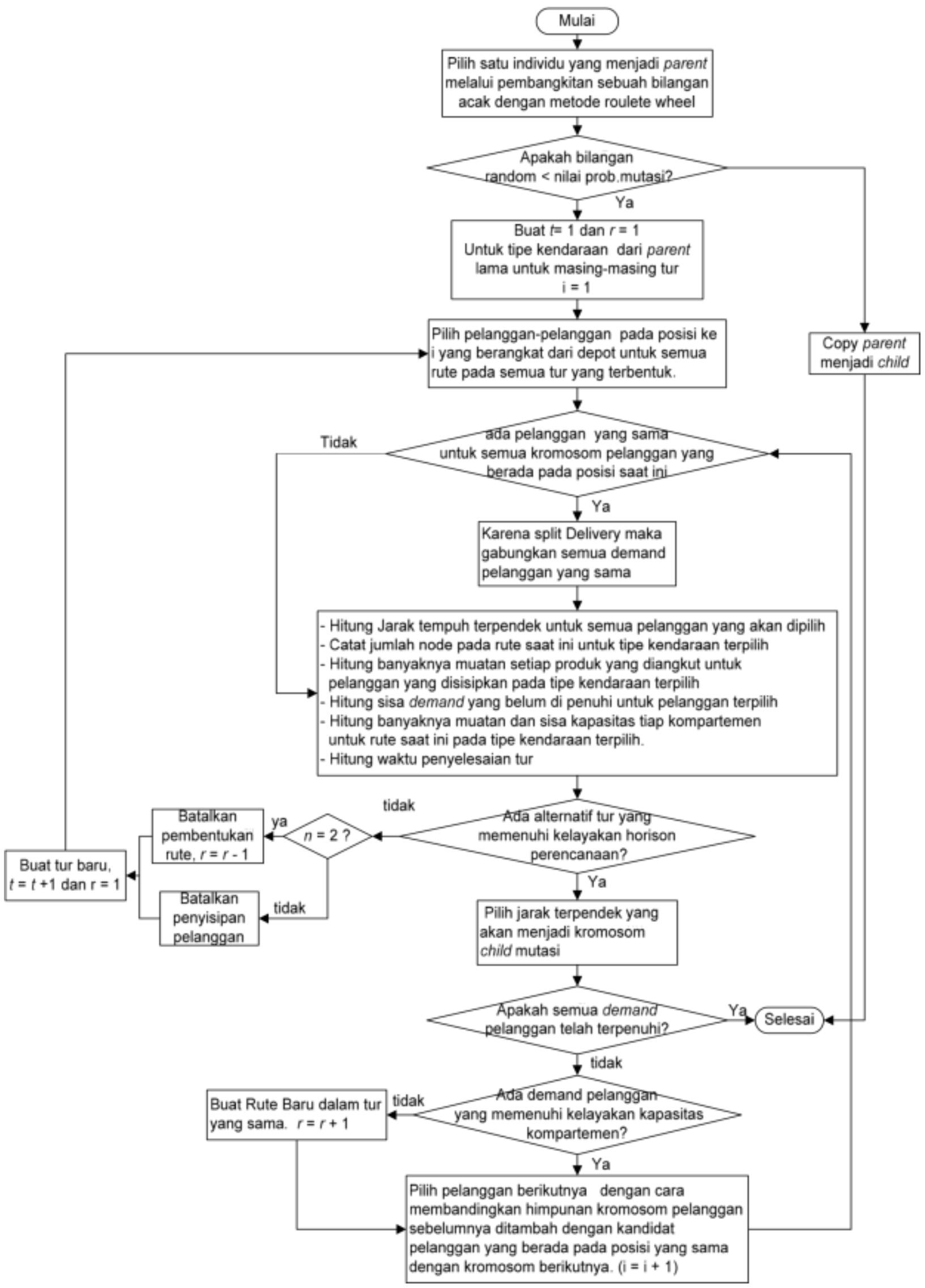

Gambar 4. Diagram alir pembentukan kromosom dalam operator mutasi 


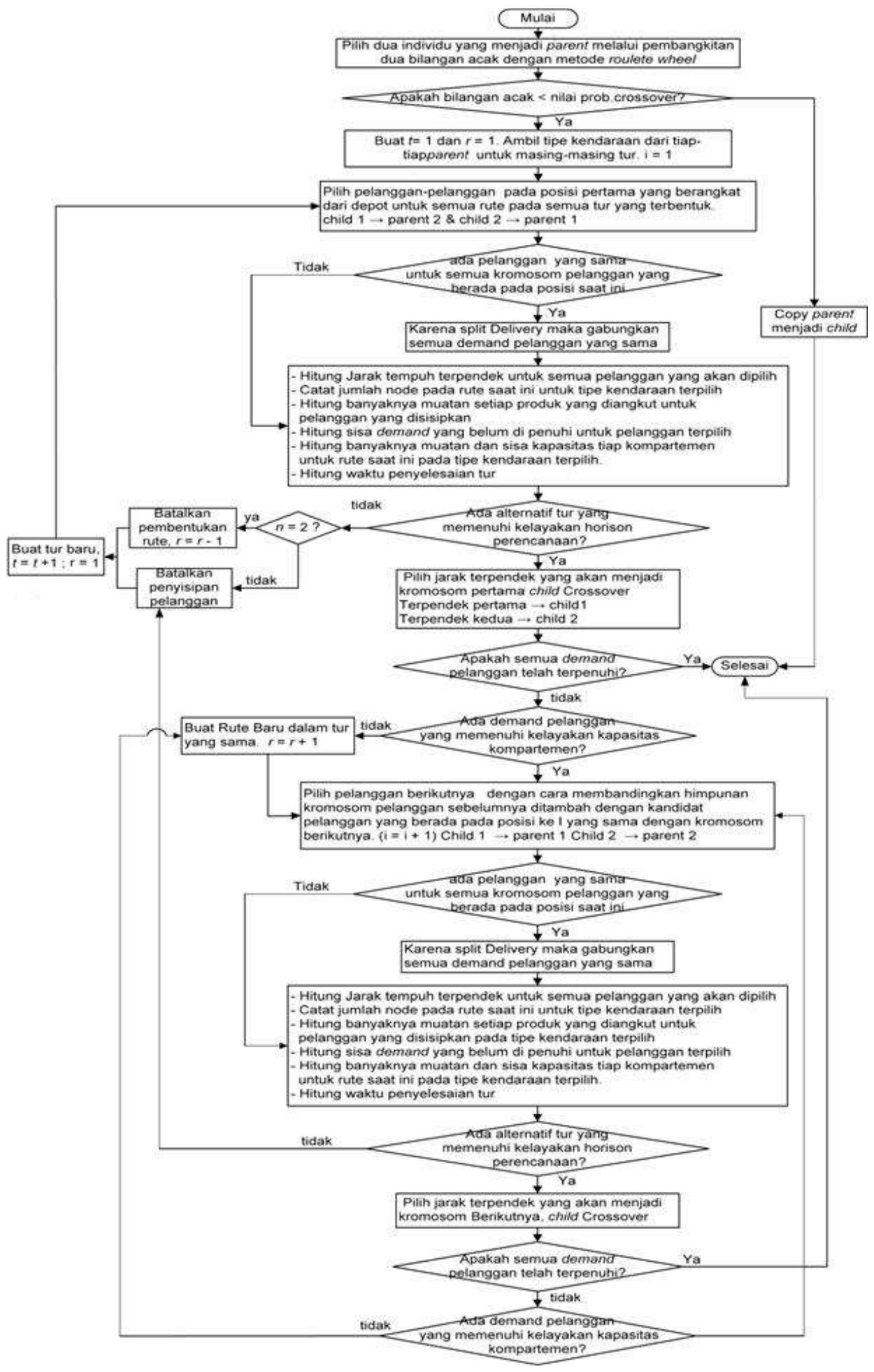

Gambar 5. Diagram alir pembentukan child crossover 
Migrasi. Proses migrasi dilakukan untuk menghasilkan subpopulasi yang diharapkan kromosomkromosom baru yang terbentuk akan lebih baik. Proses migrasi ini akan menghasilkan kromosom yang beragam sehingga memperbesar ruang pencarian solusi dari AG dengan cara mengambil informasi dari kromosom-kromosom generasi sebelumnya, rute diatur ulang untuk setiap penyisipan pelanggan. Kromosom baru yang dihasilkan, sebelumnya ditentukan migration ratenya yaitu berapa jumlah kromosom baru yang akan dibentuk.

Mutasi. Operator mutasi yang digunakan adalah tour reinsertion. Kromosom yang akan dimutasi dipilih secara random dari populasi saat ini dengan metode roulette wheel. Jika nilai fitness dari kromosom hasil mutasi tidak lebih baik dari kromosom terpilih, maka kromosom terpilih tetap dipertahankan dan masuk ke populasi berikutnya. Gambar 4 menunjukkan diagram alir prosedur pembentukan kromosom dalam operator mutasi.

Crossover. Crossover merupakan penggabungan dua string induk menjadi dua string anak (child) yang berbeda dengan string induknya dengan cara mempertukarkan (mengambil informasi) bagian dari string induk. Proses crossover ini menggunakan insertion based crossover. Diambil pelanggan pada posisi pertama dari semua rute dalam tur untuk kedua parent (child 1 dari parent 2 dan child 2 dari parent 1), yang kemudian akan disisipkan dengan kriteria pemilihan pelanggan berdasarkan jarak terpendek. Dua string induk akan dipilih dengan metode seleksi yang telah ditentukan sebelumnya. Hasil crossover ini akan dihitung fitness functionnya. Jika lebih baik dari pada kedua parent, maka hasil crossover ini akan menjadi kromosom generasi berikutnya. Proses crossover antara parent yang terpilih akan menghasilkan child dengan harapan fitness function yang dihasilkan child lebih baik dari parent. Berikut adalah Gambar 5 diagram alir prosess crossover:

\section{Hasil dan Pembahasan}

Metode AG yang diusulkan diimplementasikan dalam perangkat lunak yang dibangun dengan bahasa pemrograman Visual Basic 6.0. Untuk uji coba, perangkat lunak dijalankan pada komputer personal dengan spesifikasi prosesor Intel Core 2 Duo $1,8 \mathrm{GHz}$, memori DDR2 $3 \mathrm{~GB}$ dan sistem operasi Microsoft Windows Vista Home Premium.

Uji coba dilakukan dengan menggunakan sembilan contoh data hipotetik (disebut dengan S1, S2, S3, $\mathrm{K} 1, \mathrm{~K} 2, \mathrm{~K} 3$, C1, C2, dan C3) yang dibagi menjadi tiga kelompok menurut karakteristik lokasi pelanggan. Contoh-contoh data S1, S2, dan S3 adalah contoh-contoh data dengan lokasi yang tersebar.
Contoh-contoh data K1, K2, dan K3 adalah contohcontoh data dengan lokasi yang terkelompok. Sementara itu, contoh-contoh data C1, C2, dan C3 adalah contoh-contoh data dengan lokasi yang merupakan campuran tersebar dan terkelompok. Untuk masing-masing contoh data hipotetik, terdapat 50 pelanggan dengan lokasi pelanggan dinyatakan dalam koordinat $(x, y)$ dengan batas-batas koordinat $(0,0)$ hingga $(10,10)$. Lokasi depot terdapat pada koordinat $(5,5)$. Gambar 6 menunjukkan peta untuk contoh-contoh S1, K1, dan C1. Jarak antar lokasi didefinisikan sebagai jarak Euclidean. Satu satuan dalam peta ekivalen dengan 1 kilometer $(\mathrm{km})$.

Produk yang dikirimkan terdiri dari tiga jenis. Terdapat tiga jenis kendaraan yang digunakan dan mempunyai tiga kompartemen dengan kapasitas tertentu. Tabel 1 memperlihatkan spesifikasi data kendaraan dan kompartemen. Kecepatan kendaraan adalah $50 \mathrm{~km} / \mathrm{jam}$. Waktu muat sama dengan waktu bongkar yaitu 30 unit/jam. Waktu persiapan (setup) adalah 0,2 jam. Horison perencanaan sepanjang 10 jam.

Nilai-nilai parameter AG yang digunakan untuk uji coba adalah berikut ini: ukuran populasi $=20$, jumlah generasi maksimum $=50$, proporsi kromosom untuk elitisme $=10 \%$, proporsi kromosom untuk migrasi $=40 \%$, proporsi kromosom untuk mutasi $=$ $20 \%$ dan proporsi kromosom untuk crossover $=30 \%$.

Gambar 7 menampilkan salah satu solusi untuk contoh data $\mathrm{K} 1$ yang terdiri atas enam tur. Tur 1, 4, dan 6 dilayani oleh kendaraan jenis 1 . Tur 2 dilayani oleh kendaraan jenis 2. Sementara tur 3 dan 5 dilayani kendaraan jenis 3. Dengan demikian, kendaraan jenis 1 , 2, dan 3 yang digunakan masingmasing adalah 3 , 1 , dan 2 unit.

Metode AG merupakan salah satu metode metaheuristik yang bersifat probabilistik dalam mengeksplorasi ruang solusi. Oleh karena itu, solusi yang diperoleh akan berbeda antar replikasi. Untuk melihat kekonsistenan atau kestabilan dari AG yang diusulkan, percobaan numerik dilakukan menggunakan sembilan contoh data. Untuk setiap contoh data, replikasi dilakukan sebanyak 5 kali. Ringkasan hasil percobaan ditunjukkan pada Tabel 2 . Hasil percobaan menunjukkan bahwa AG yang diusulkan memberikan hasil yang konsisten atau stabil yang diukur dengan koefisien variasi pada nilai fungsi tujuan dan waktu komputasi. Secara keseluruhan, rata-rata koefisien variasi untuk nilai fungsi tujuan dan waktu komputasi masing-masing adalah 0,07\% dan 0,99\%. Dengan demikian, untuk tiap contoh data, solusi yang dihasilkan dari tiap replikasi dari AG yang diusulkan relatif tidak berbeda. 


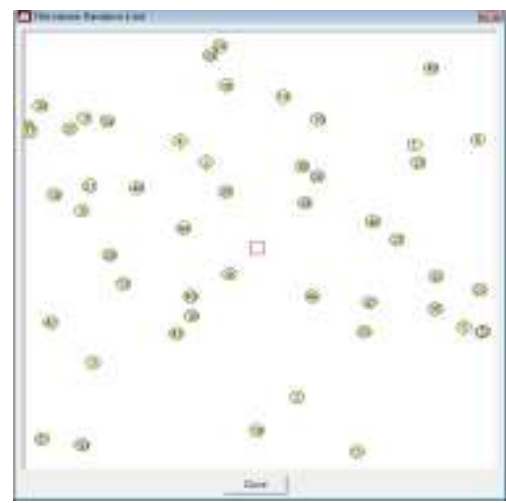

(a) Peta untuk contoh data S1

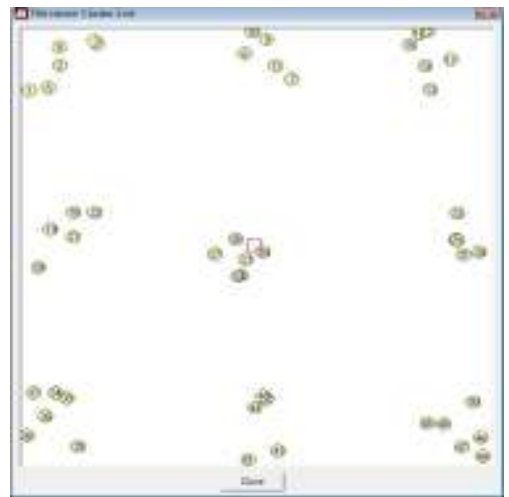

(b) Peta untuk contoh data K1

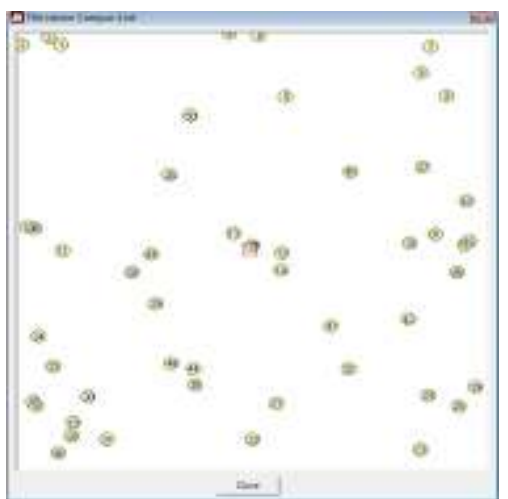

(c) Peta untuk contoh data $\mathrm{Cl}$

Gambar 6. Peta untuk contoh-contoh data S1, K1, dan C1

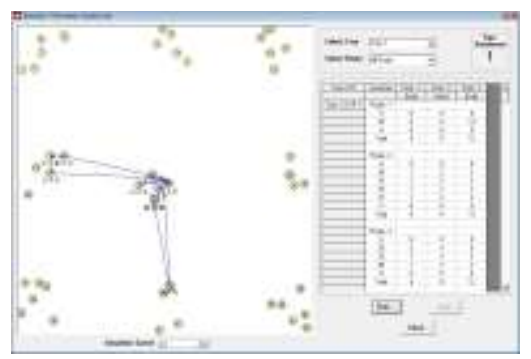

(a) Tur 1

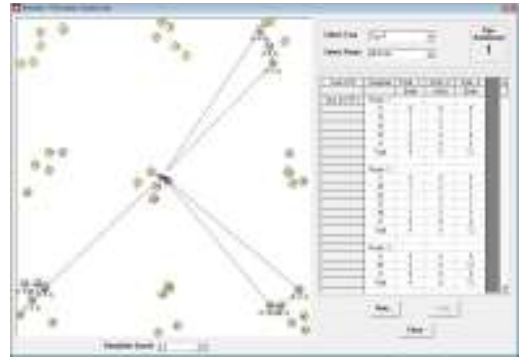

(d) Tur 4

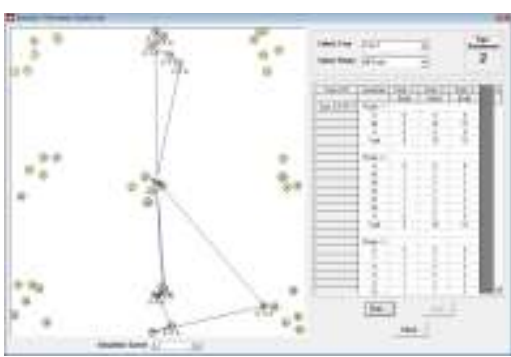

(b) Tur 2

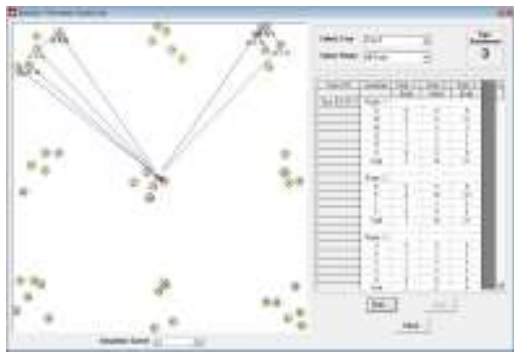

(d) Tur 5

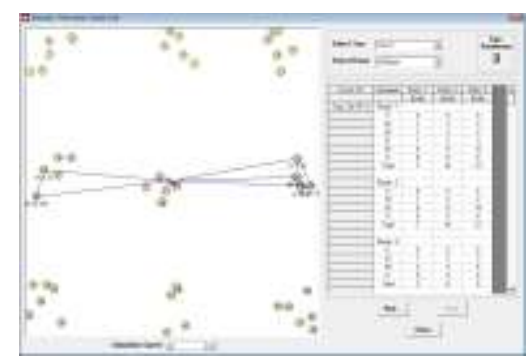

(c) Tur 3

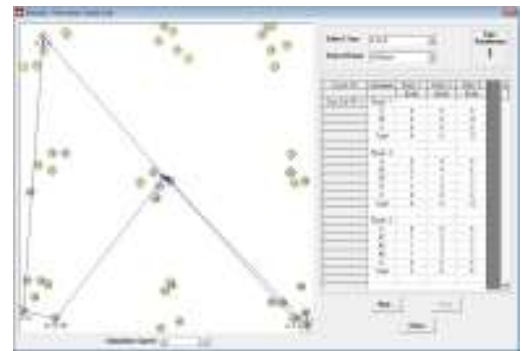

(e) Tur 6

Gambar 7. Solusi untuk contoh data K1

Tabel 1. Spesifikasi kendaraan

\begin{tabular}{cccccc}
\hline Jenis kendaraan & $\begin{array}{c}\text { Biaya tetap } \\
\text { (Rp/horizon } \\
\text { perencanaan) }\end{array}$ & $\begin{array}{c}\text { Biaya variabel } \\
\text { (Rp/jam) }\end{array}$ & $\begin{array}{c}\text { Kapasitas } \\
\text { kompartemen 1 } \\
\text { (unit) }\end{array}$ & $\begin{array}{c}\text { Kapasitas } \\
\text { kompartemen 2 } \\
\text { (unit) }\end{array}$ & $\begin{array}{c}\text { Kapasitas } \\
\text { kompartemen 3 } \\
\text { (unit) }\end{array}$ \\
\hline Jenis 1 & 100500 & 5000 & 4 & 8 & 12 \\
Jenis 2 & 101000 & 5500 & 5 & 10 & 15 \\
Jenis 3 & 101500 & 5750 & 7 & 14 & 21 \\
\hline
\end{tabular}

Tabel 2. Hasil komputasi dengan contoh data hipotetik

\begin{tabular}{ccccccc}
\hline \multirow{2}{*}{ Contoh data } & \multicolumn{3}{c}{ Total biaya (Rp) } & \multicolumn{2}{c}{ Waktu komputasi (detik) } \\
\cline { 2 - 6 } & Rata-rata & $\begin{array}{c}\text { Simpangan } \\
\text { baku }\end{array}$ & $\begin{array}{c}\text { Koefisien } \\
\text { variasi }\end{array}$ & Rata-rata & $\begin{array}{c}\text { Simpangan } \\
\text { baku }\end{array}$ & $\begin{array}{c}\text { Koefisien } \\
\text { variasi }\end{array}$ \\
\hline S1 & 627062,20 & 277,96 & $0,04 \%$ & 46,85 & 1,22 & $2,60 \%$ \\
S2 & 627619,00 & 423,78 & $0,07 \%$ & 45,84 & 0,61 & $1,34 \%$ \\
S3 & 628230,60 & 309,01 & $0,05 \%$ & 45,15 & 0,12 & $0,27 \%$ \\
K1 & 629162,20 & 351,69 & $0,06 \%$ & 44,72 & 0,14 & $0,32 \%$ \\
K2 & 628727,20 & 423,60 & $0,07 \%$ & 44,77 & 0,61 & $1,36 \%$ \\
K3 & 629460,00 & 926,04 & $0,15 \%$ & 45,55 & 0,60 & $1,31 \%$ \\
C1 & 628798,20 & 500,46 & $0,08 \%$ & 45,17 & 0,15 & $0,33 \%$ \\
C2 & 628263,20 & 485,71 & $0,08 \%$ & 44,90 & 0,38 & $0,85 \%$ \\
C3 & 628661,20 & 448,72 & $0,07 \%$ & 44,88 & 0,23 & $0,50 \%$ \\
\hline Rata-rata & 628442,64 & 460,77 & $0,07 \%$ & 45,31 & 0,45 & $0,99 \%$ \\
\hline
\end{tabular}




\section{Simpulan}

Makalah ini telah masalah rute kendaraan (MRK) yang mencakup karakteristik-karakteristik: ukuran dan campuran armada, trip majemuk, pengiriman terbagi, produk majemuk, dan kendaraan dengan kompartemen majemuk. Algoritma genetika (AG) telah diusulkan sebagai metode pemecahan.

Metode AG merupakan salah satu metode metaheuristik yang bersifat probabilistik dalam mengeksplorasi ruang solusi. Oleh karena itu, solusi yang diperoleh akan berbeda antar replikasi. Percobaan numerik dengan contoh-contoh data hipotetik menunjukkan bahwa AG yang diusulkan memberikan hasil yang konsisten atau stabil yang diukur dengan koefisien variasi dari nilai fungsi tujuan dan waktu komputasi. Dengan demikian, untuk tiap contoh data, solusi yang dihasilkan dari tiap replikasi dari AG yang diusulkan relatif tidak berbeda.

Kinerja (efektivitas dan efisiensi) dari AG yang diusulkan sangat tergantung pada nilai-nilai parameter algoritma yang ditetapkan seperti ukuran populasi, jumlah generasi maksimum, dan proporsi untuk elistisme, migrasi, mutasi, dan crossover. Penelitian lebih lanjut dapat dilakukan untuk mengetahui efek dari nilai-nilai dari parameter terhadap kinerja AG dan menentukan setelan nilainilai parameter yang memberikan kinerja yang terbaik.

Dalam makalah ini, analisis hanya dilakukan untuk melihat kekonsistenan dari kinerja AG yang diukur dengan koefisien variasi dari nilai fungsi tujuan dan waktu komputasi. Penelitian lanjutan dapat dilakukan dengan mengembangkan metode-metode pemecahan lain sehingga kinerja dari AG yang diusulkan dapat dibandingkan. Selain itu, MRK yang dibahas dalam makalah ini belum dirumuskan dalam model matematis. Melalui adanya model matematis untuk MRK ini, solusi-solusi yang diperoleh dengan pemecahan model matematis dapat digunakan sebagai pembanding dari kenerja metode AG yang diusulkan.

\section{Daftar Pustaka}

1. Dantzig, G. B. and Ramser, J., The Truck Dispatching Problem, Management Science, 6(1), 1959, pp. 80-91.

2. Wassan, N. A. and Osman, I. H., Tabu Search Variant for the Mix Fleet Vehicle Routing Problem, Journal of the Operational Research Society, 53(7), 2002, pp. 768-782.

3. Lee, Y. H., Kim, J. I., Kang, K. H. and Kim, K. H., A Heuristic for Vehicle Fleet Mix Problem using Tabu Search and Set Partitioning, Journal of the Operational Research Society, 59(6), 2008, pp. 833-841.
4. Gheysens, F., Golden, B., and Assad, A., A Comparison of Techniques for Solving the Fleet Size and Mix Vehicle Routing Problem, OR Spektrum, 6(4), 1984, pp. 207-216.

5. Brandão, J. and Mercer, A., A Tabu Search Algorithm for the Multi-Trip Vehicle Routing and Scheduling Problem, European Journal of Operational Research, 100(1), 1997, pp. 180-191.

6. Taillard, É. D., Laporte, G. and Gendreau, M., Vehicle Routeing with Multiple Use of Vehicles, Journal of the Operational Research Society, 47(8), 1996, pp. 1065-1070.

7. Brandão, J. C. S and Mercer, A., The Multi-Trip Vehicle Routing Problem, Journal of the Operational Research Society, 49(8), 1998, pp. 799-805.

8. Zhao, Q. -H, Wang, S. -Y., Lai, K. K. and Xia, G. -P., A Vehicle Routing Problem with Multiple Use of Vehicles, Advanced Modeling and Optimization, 4(3), 2002, pp. 31-40.

9. Petch, R. J. and Salhi, S., A Multi-Phase Constructive Heuristic for the Vehicle Routing Problem with Multiple Trips, Discrete Applied Mathematics, 133(1-3), 2004, pp. 69-92

10. Salhi, S. and R. J. Petch, R. J., A GA based Heuristic for the Vehicle Routing Problem with Multiple Trips, Journal of Mathematical Modelling and Algorithms, 6(4), 2007, pp. 591-613.

11. Dror, M, Laporte, G. and Trudeau, P., Vehicle Routing with Split Deliveries, Discrete Applied Mathematics, 50(3), 1994, pp. 239-254.

12. Archetti, C., Speranza, M. G. and Hertz, A., A Tabu Search Algorithm for The Split Delivey Vehicle Routing Problem, Transportation Science, 40(1), 2006, pp. 64-73.

13. Boudia, M., Prins, C. and Reghioui, M., An Effective Memetic Algorithm with Population Management for the Split Delivery Vehicle Routing Problem, Proceedings of the 4th International Conference on Hybrid Metaheuristics, Dortmund, Germany, 2007.

14. Tavakkoli-Moghaddam, R., Safaei,N., Kah, M. M. O. and Rabbani, M., A New Capacitated Vehicle Routing Problem with Split Service for Minimizing Fleet Cost by Simulated Annealing, Journal of the Franklin Institute, 344, 2007, pp. 406-425.

15. Derigs, U, Li, B. and Vogel, U., Local SearchBased Metaheuristics for the Split Delivery Vehicle Routing Problem, Journal of the Operational Research Society, 61(9), 2010, pp. 13561364.

16. Wilck IV, J. H. and Cavalier, T. M., A Construction Heuristic for the Split Delivery Vehicle Routing Problem, American Journal of Operations Research, 2, 2012, pp. 153-162.

17. Christofides, N., Mingozzi, A. and Toth, P., The Vehicle Routing Problem, in Combinatorial Optimization, Chichester, UK, Wiley, 1979, pp. 315-338. 
18. Chajakis, E. D. and Guignard, M., Scheduling Deliveries in Vehicles with Multiple Compartments, Journal of Global Optimization, 26, 2003, pp. 43-78.

19. El Fallahi, A., Prins, C., and Calvo, R. W., A Memetic Algorithm and a Tabu Search for the Multi-Compartment Vehicle Routing Problem, Computers \& Operations Research, 35(5), 2008, pp. 1725-1741.

20. Avella, P., Boccia, M. and A. Sforza, Solving a Fuel Delivery Problem by Heuristics and Exact Approaches, European Journal of Operational Research, 152(1), 2004, pp. 170-179.

21. Derigs, U, Gottlieb, J., Kalkof, J., Piesche, M., Rothlauf, F. and Vogel, U. Vehicle Routing with Compartments: Applications, Modelling and Heuristics, OR Spectrum, 33 (4), 2011, pp. 885914.

22. Reed, M, Yiannakou, A. and Evering, R., An Ant Colony Algorithm for the Multi-Compartment Vehicle Routing Problem, Applied Soft Computing, 15, 2014, pp. 169-176.

23. Suprayogi and Komara, S., A Sequential Insertion Algorithm for Solving a Distribution Problem of Fuel Products, JSPS Seminar on
Marine Transportation Engineering, Hiroshima, Japan, 2006.

24. Suprayogi, Komara, S. and Yamato, H., Local Search Technique for Solving a Delivery Problem of Fuel Products, Proceedings of the 2nd International Conference on Operations and Supply Chain Management, Bangkok, Thailand, 2007.

25. Suprayogi dan Arvianto, A., Masalah Rute Kendaraan dengan Rute Majemuk, Jendela Waktu Majemuk, Pengiriman Terbagi, Produk Majemuk dan Kompartemen Majemuk, Prosiding Seminar Nasional Teknik Industri BKSTI 2014, Bukittinggi, Indonesia, 2014, pp. IV-122IV-128.

26. Arvianto, A., Setiawan, A. H. dan Saptadi, S., Model Vehicle Routing Problem dengan Karakteristik Rute Majemuk, Multiple Time Windows, Multiple Products dan Heterogeneous Fleet untuk Depot Tunggal, Jurnal Teknik Industri, 16(2), 2014, pp. 85-96.

27. Paillin, D. B. dan Wattimena, E., Penerapan Algoritma Sequential Insertion dalam Pendistribusian BBM di Kawasan Timur Indonesia (Studi Kasus pada PT Pertamina UPMS VIII Terminal Transit Wayame-Ambon), ARIKA, 9(1), 2015, pp. 53-62. 